\title{
Insights of the pathophysiology of neurodegenerative diseases and the role of phytochemical compounds in its management
}

\author{
Zurina Hassan ${ }^{1 *}$ and Raghava N. Sriramaneni ${ }^{2}$ \\ ${ }^{1}$ Centre for Drug Research, Universiti Sains Malaysia, 11800 Penang, Malaysia. \\ 2 Department of Human Oncology, University of Wisconsin, Wisconsin, USA. \\ * Correspondence: zurina hassan@usm.my; Tel.: +6017-5500804
}

Published: 28 August 2021

https://doi.org/10.31117/neuroscirn.v4i3.77

Keywords: Neurodegenerative disease; Alzheimer's disease; Parkinson's disease; active compounds; pathophysiology

(C2021 by Hassan \& Sriramaneni for use and distribution according to the Creative Commons Attribution (CC BYNC 4.0) license (https://creativecommons.org/licenses/by-nc/4.0/), which permits unrestricted non-commercial use, distribution, and reproduction in any medium, provided the original author and source are credited.

A neurodegenerative disease (ND) is defined as an irreversible disorder in most cases, leading to progressive loss of neurons and intellectual abilities. ND can lead to fatality in most circumstances, and the elderly above the age of sixty-five (65) constitute the major risk category. The most common type of ND includes Alzheimer's disease (AD), and Parkinson's disease (PD). Other NDs are Huntington's disease (HD), motor neuron disease (MND), spinocerebellar ataxia (SCA), spinal muscular atrophy (SMA), and prion disease. ND strikes mainly in the middle to late life incidence expected to rise as the population ages. According to Harvard NeuroDiscovery Center, by the year 2030, 1 in every 5 Americans over the age of 65, if left untreated, may cause more than 12 million Americans to suffer from ND (Harvard NeuroDiscovery Center, 2021). According to Center for Disease Control and Prevention (CDC), 1 in every 3 seniors with AD will die as a result of dementia or the COVID-19 pandemic (Alzheimer's Association, 2021).

The hallmarks of ND are protein aggregation, mitochondrial dysfunction, neuronal loss via apoptosis or necrosis, lysosomal dysfunction, excitotoxicity and metabolic syndrome. Increasing evidence demonstrates that metabolic syndrome is interrelated with many NDs because it affects middle-aged or older adults (Yalcin \&
Yalcin, 2018). During neurodegeneration, an innate immune response acts as the first line of defence to protect the host against invading pathogens (Medzhitov, 2008). Immune resident cells in the brain, such as microglia, have a vital homeostatic function, including the phagocytosis of fragmented and dying cells (Salter \& Stevens, 2017). However, activated microglia produce large amounts of free radicals and contribute significantly to inflammation in AD (Wolozin \& Behl, 2000). This inflammatory activity is beneficial for a short period. However, during ageing and in chronic neurodegenerative disease, both the innate and peripheral immune systems are defective and fail to detect or respond to imbalances in homeostasis due to the accumulation of protein aggregates. Subsequently, prolonged neuroinflammation with higher levels of proinflammatory cytokines leads to harmful consequences in CNS.

It is critical to note that protein abnormalities that define ND can be presented before the onset of clinical features (Dugger \& Dickson, 2017). In ND, abnormal protein conformations and cellular and neuroanatomical distribution constitute the major histopathologic features essential for disease state diagnosis (Kovacs, 2016). These proteins are considered NDs biomarkers. For instance, $A D$ is characterised by the 
extracellular deposition of $A \beta$ fibrils, abnormally phosphorylated tau protein accumulation, neuritic senile plaques, and neurofibrillary tangles (Marks et al., 2017). In addition, prion diseases are a cellular form of prion protein $(\mathrm{PrPc})$ and scrapie isoform of prion protein (PrPSc) (Mehrpour \& Codogno, 2012) whereas $\alpha$ synuclein protein (Dauer \& Przedborski, 2003) and Lewy bodies (Licker et al., 2009) have key roles in the neuropathology of PD. In HD, unstable huntingtin (Htt) protein aggregates accumulate in neurones leading cell death (Roos, 2010). MND is contributed by glutamate excitotoxicity of neurones (Relja, 2004), whereas loss of motor neurons in the spinal cord is observed in SMA (Coovert et al., 1997). In SCA, aggregation of proteins with long polyglutamine tract (PolyQ) forming inclusions in the cytoplasm or nucleus of vulnerable neurones, contributing to the progression of the pathology such as neuronal dysfunctions and subsequent neurodegeneration (Pilotto \& Saxena, 2018).

Many models and ideas have been used to identify the exact pathophysiology and mechanisms of ND. The most frequently discussed risk amongst the general population with ND is ageing. Human brain ageing can be investigated using aged non-human primates and some other higher-order animal species. However, it is challenging to monitor complete neuropathological or clinical phenotypes seen in humans in these models. Hence, cell models, animal models, and genetically engineered non-mammals (Caenorhabditis elegans, Drosophila melanogaster and zebrafish) are employed to recapitulate the specific disease mechanisms involved in ND, including the screening of therapeutic compounds. The genetically engineered mice have been the most popular and widely used animal model to study ND (Trancikova et al., 2011). The commonly used study model for $A D$ research includes the transgenic animal model targeting amyloid-beta precursor protein (APP), presenilin, tau or the human apolipoprotein $E$ gene $(A P O E)$ gene. For PD research, classic neurotoxininduced animals are usually employed. Several compounds known to be toxic to dopaminergic neurones can be used to produce parkinsonism, such as 1-methyl-4-phenyl-1,2,3,6-tetrahydropyridine (MPTP), paraquat, rotenone and 6-hydroxydopamine. Animal models of HD include both toxin-induced models (mitochondrial toxin 3-nitropropionic acid or excitotoxins such as kainate, ibotenate, quinolinate), genetic models such as transgenic mice (R6/2, R6/1, N171-82Q, Yeast artificial chromosome expressing complete human htt protein) and knock-in mouse model (HdhQ92 mouse, HdhQ111 mouse, CAG140 mouse, CAG150 mouse) (Ramaswamy et al., 2007).
Unfortunately, several clinical trials targeting ND have raised doubts about the translatability of animal disease models to humans. To bridge the gap between animal and human studies, three-dimensional (3D) cell culture models have been developed from human or animal cells. Traditionally, two-dimensional (2D) cell culture was used in vitro, but its efficiency is questionable because the environment is far from mimicking the in vivo state. Hence, the 3D cell culture creates an artificial environment that allows the biological cells to grow and interact to mimic a living organ and its microarchitecture. There are several advantages of 3D model such as (1) allows better control of variables that are difficult to regulate in vivo; (2) reproducible cellular and molecular mechanism; (3) allows human-based models to be grown by using human cells for drug testing, disease modelling and diagnoses; (4) can overcome the graft limitations; (5) allows faster and affordable translational studies involving the identification of the mechanism of action together with any associated risks (Bédard et al., 2020; Slanzi et al., 2020).

Pathological changes of neurons and loss of synaptic protein are the key features in many ND, including dementia. The latter seems to be directly linked to cognitive deficits from the early stages of dementia and precede neuronal degeneration (Bereczki et al., 2018; Kashyap et al., 2019; Sharifi-Rad et al., 2020a). As shown in Figure 1, synaptic loss was established from activated microglia, which engulf and excessively prune the synapses. In addition, the activated microglia also release pro-inflammatory cytokines, which can have direct excitotoxic effects on the synapses (Hong et al., 2016; Wang et al., 2015). Current therapeutic interventions focus on the treatment of neuronal loss or synaptopathy targeting at the theoretically distinct processes of maintenance, compensation, and recovery of synaptic function, which can significantly impact cognitive function (Sheng et al., 2012). Most of the new drug discoveries in an attempt to improve the efficiency of remaining synapses in brains were based on its pharmacological classes such as anti-cholinesterase (Anand \& Singh, 2013), selective serotonin reuptake inhibitors (Chow et al., 2007) and N-methyl-D-aspartic acid (NMDA) antagonists (Prentice et al., 2015).

The most common physiological symptoms of ND are elevated oxidative/nitrosative stress, mitochondrial dysfunction, protein misfolding /aggregation, synapse loss, and decreased neuronal survival. This chronic neurodegenerative disorder leads to progressive dementia and deterioration of cognitive function. 


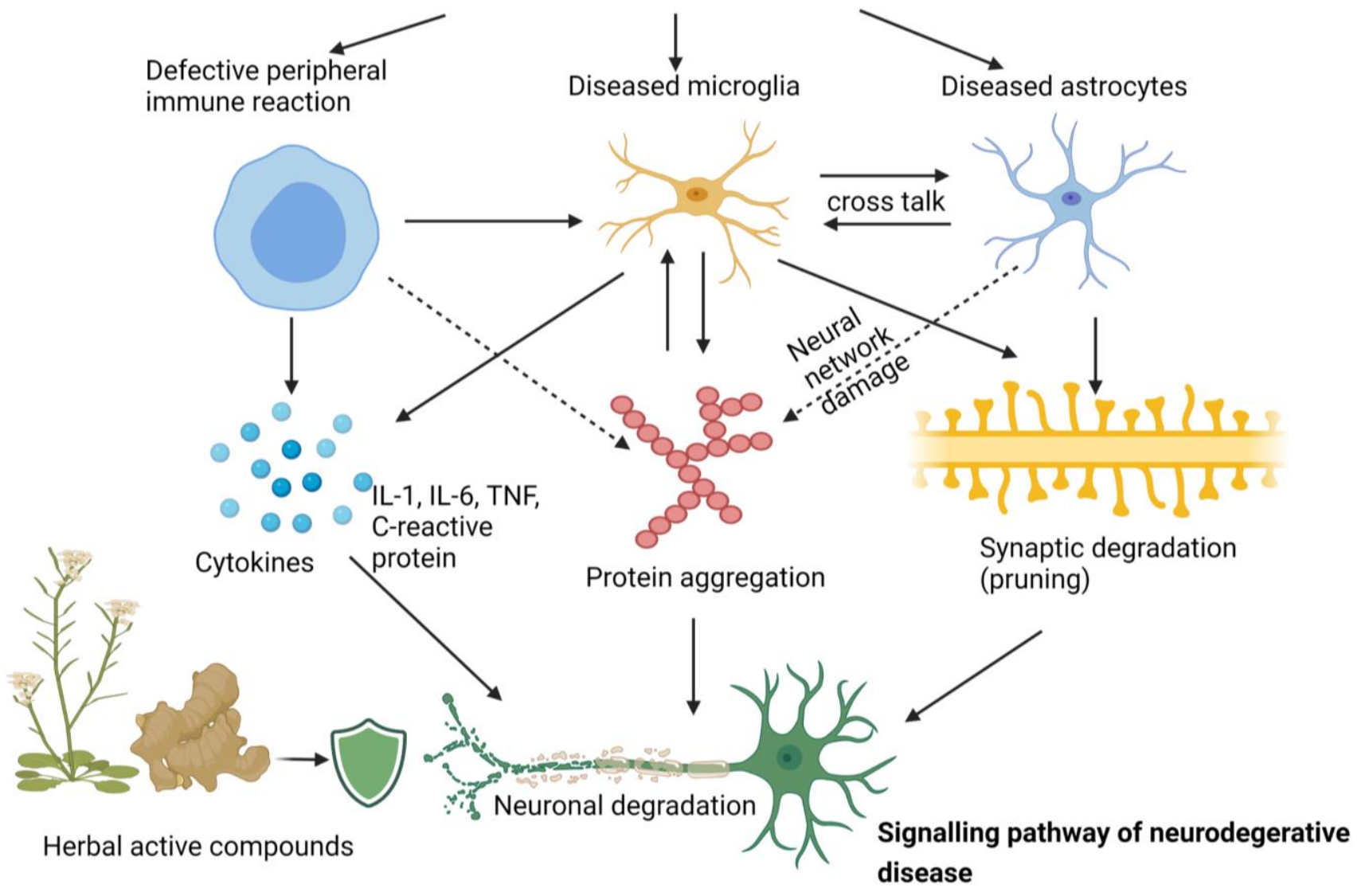

Figure 1: Signalling pathway of neurodegenerative disease. Defective innate immune reactions associated with ageing contributes to neurodegenerative diseases. Brain resident microglia and astrocytes can cross-talk each other and help to form the protein aggregates and damages the neuronal network with the help of pro-inflammatory cytokines such as interleukin-1 (IL-1), interleukin-6 (IL-6), tumour necrosis factor-alpha (TNF- $\alpha$ ) and C-reactive protein. Alternatively, synaptic pruning and microglia can also agonise neuronal degradation independent of protein aggregation (Gan et al., 2018). Herbal active compounds listed in Table 1 can antagonise these signalling responses and protect against neuronal cell damage.

Current available drugs focus primarily on temporary symptomatic relief. Hence, there is a high demand for the discovery of novel therapies and neuroprotective agents to prevent and retard the progression of ND (Sharifi-Rad et al., 2020b). Recently, some convincing evidence has been published regarding the use of traditional herbs and phytochemicals to delay the onset and slow the progression of ND. Most of the traditional herbal medicines are prepared from crude materials, and there are concerns about their specific medicinal effects and reproducibility, mode of action and the active ingredients (Kim et al., 2010). Furthermore, these natural phytochemicals are less toxic than novel synthetic drugs. Hence, many active compounds have been isolated and identified from medicinal plant extracts (Ansari \& Khodagholi, 2013). These include lignans, flavonoids, tannins, polyphenols, triterpenes, sterols, and alkaloids, which have shown various beneficial pharmacological activities, such as antiinflammatory, anti-amyloidogenic, anti-cholinesterase, anti-oxidant, inhibiting protein misfolding, reducing neuroinflammation, anti-apoptotic, neurotrophic, acetylcholinesterase (AChE) inhibition, monoamine oxidase (MAO) inhibition and anti-thrombotic (Howes et al., 2003; Sharifi-Rad et al., 2020b).

Neurotrophins play a vital role in the survival, maintenance and regeneration of specific neuronal populations in the brain (Baazaoui \& labal, 2018). Examples of these neurotrophins are nerve growth factor (NGF), brain-derived neurotrophic factor (BDNF), neurotrophin-3 (NT-3), and NT-4/5. Neurotrophins depletion accelerates the progression of ND, and therefore, replacing such neurotrophins is potentially therapeutic (Venkatesan et al., 2015). Phytochemicals from natural sources and synthetic derivatives have 
Table 1: List of selected potential herbal drugs with its active constituents for the treatment of neurodegenerative diseases.

\begin{tabular}{|c|c|c|c|}
\hline Name of the plant & Active constituents & Uses & References \\
\hline $\begin{array}{l}\text { Ginkgo } \\
\text { Ginkgo biloba }\end{array}$ & $\begin{array}{l}\text { Terpene trilactones, ginkgolides } \\
\text { A, B, C, J and bilobalide, } \\
\text { biflavones, proanthocyanidins, } \\
\text { alkylphenols, polyprenols }\end{array}$ & $\begin{array}{l}\text { To treat moderate dementia and } \\
A D \text {, improve memory, } \\
\text { neuroprotection }\end{array}$ & $\begin{array}{l}\frac{\text { Van Beek, } 2002}{\text { Defeudis, } 2002} \\
\text { Tchantchou et al., } 2009 \\
\text { Yakoot et al., 2013 } \\
\end{array}$ \\
\hline $\begin{array}{l}\text { Rosemary } \\
\text { Salvia rosmarinus }\end{array}$ & $\begin{array}{l}\text { Rosmarinic acid, carnosic acid, } \\
\text { camphor, caffeic acid, ursolic } \\
\text { acid, betulinic acid, } \\
\text { rosmaridiphenol and rosmanol }\end{array}$ & $\begin{array}{l}\text { Improves memory, prevents } \\
\text { stroke, to treat } A D \text {, anti-oxidant, } \\
\text { antibacterial, anti-inflammatory, } \\
\text { anticancer, antiviral and } \\
\text { neuroprotective effects }\end{array}$ & 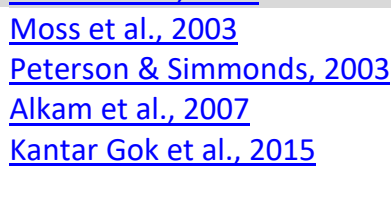 \\
\hline $\begin{array}{l}\text { Turmeric } \\
\text { Curcuma longa }\end{array}$ & Curcumin & $\begin{array}{l}\text { To treat } A D \text {, anticancer, } \\
\text { antidiabetic neuroprotective, } \\
\text { reducing } \alpha \text {-synuclein } \\
\text { oligomerisation in PD }\end{array}$ & $\begin{array}{l}\frac{\text { Funk et al., } 2006}{\text { Mishra \& Palanivelu, } 2008} \\
\text { Aggarwal et al., } 2006 \\
\text { Hamaguchi et al., } 2010\end{array}$ \\
\hline $\begin{array}{l}\text { Ginseng } \\
\text { Panax ginseng }\end{array}$ & $\begin{array}{l}\text { Ginsenosides, or saponins, } 20(\mathrm{~S}) \text { - } \\
\text { protopanaxadiol (PPD) and 20(S)- } \\
\text { protopanaxatriol (PPT) }\end{array}$ & $\begin{array}{l}\text { To treat neurological disorders } \\
\text { such as PD, AD, and stroke }\end{array}$ & $\begin{array}{l}\text { Tawab et al., } 2003 \\
\text { Cho, } 2012\end{array}$ \\
\hline $\begin{array}{l}\text { Brahmi } \\
\text { Bacopa monnieri }\end{array}$ & $\begin{array}{l}\text { Saponins, triterpenoids, } \\
\text { alkaloids, sterols, betulinic acid, } \\
\text { polyphenols and sulfhydryl }\end{array}$ & $\begin{array}{l}\text { Nerve tonic, antidiuretic, to treat } \\
\text { rheumatism, epilepsy, insomnia, } \\
\text { improves memory and treatment } \\
\text { of } A D\end{array}$ & Gohil \& Patel, 2010 \\
\hline $\begin{array}{l}\text { Shankhapushpi } \\
\text { Convolvulus } \\
\text { pluricaulis }\end{array}$ & $\begin{array}{l}\text { triterpenoids, flavonol } \\
\text { glycosides, anthocyanins, and } \\
\text { steroids }\end{array}$ & $\begin{array}{l}\text { Nootropic and memory-enhancing } \\
\text { activity, anti-stress, treatment of } \\
\text { anxiety, mental fatigue, and } \\
\text { insomnia, treat AD }\end{array}$ & $\begin{array}{l}\text { Sethiya et al., } 2009 \\
\text { Malik et al., } 2011\end{array}$ \\
\hline $\begin{array}{l}\text { Gotu kola } \\
\text { Centella asiatica }\end{array}$ & Asiatic acid and asiaticoside & $\begin{array}{l}\text { Improves memory, } \\
\text { neuroprotection, anti-oxidant, AD } \\
\text { and PD treatment }\end{array}$ & 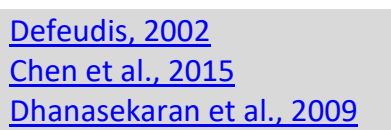 \\
\hline $\begin{array}{l}\text { Ginger } \\
\text { Zingiber officinale }\end{array}$ & $\begin{array}{l}\text { gingerols, shagoals, bisabolene, } \\
\text { zingiberene, and monoterpenes }\end{array}$ & Enhances cognitive functions in AD & $\begin{array}{l}\text { Ali et al., } 2008 \\
\text { Oboh et al., } 2012\end{array}$ \\
\hline $\begin{array}{l}\text { Garlic } \\
\text { Allium sativum }\end{array}$ & Allicin & $\begin{array}{l}\text { Neuroprotection, improve } \\
\text { memory, anti-oxidant, treatment } \\
\text { of } A D \text {, ischemia }\end{array}$ & $\begin{array}{l}\text { Essa et al., } 2012 \\
\text { Borek, } 2006 \\
\text { Nillert et al., } 2017 \\
\end{array}$ \\
\hline $\begin{array}{l}\text { Citrus } \\
\text { Citrus sinensis }\end{array}$ & Quercetin & $\begin{array}{l}\text { Anti-oxidant, anticancer, antiviral, } \\
\text { anti-inflammatory, treat } A D, \\
\text { reduce MAO }\end{array}$ & $\begin{array}{l}\frac{\text { Ossola et al., } 2009}{\text { Russo et al., } 2012} \\
\frac{\text { Bischoff, } 2008}{\text { Jiménez-Aliaga et al., } 2011}\end{array}$ \\
\hline $\begin{array}{l}\text { Tea } \\
\text { Camellia sinensis }\end{array}$ & Epigallocatechin-3-gallate & $\begin{array}{l}\text { Anti-oxidant, anticancer, treatment } \\
\text { of ND and } A D\end{array}$ & $\begin{array}{l}\text { Ahmad et al., } 1997 \\
\text { Biasibetti et al., } 2013 \\
\text { Lee et al., } 2009 \\
\end{array}$ \\
\hline $\begin{array}{l}\text { Chinese goldthread } \\
\text { Coptis chinensis }\end{array}$ & Berberine & $\begin{array}{l}\text { Anti-oxidant, treat } A D \text {, improve } \\
\text { memory, } A C h E \text { inhibitor }\end{array}$ & $\begin{array}{l}\text { Kulkarni \& Dhir, } 2010 \\
\text { Durairajan et al., } 2012 \\
\text { Zhu \& Qian, } 2006 \\
\text { Huang et al., 2017 }\end{array}$ \\
\hline $\begin{array}{l}\text { Grapevine } \\
\text { Vitis vinifera }\end{array}$ & Resveratrol & $\begin{array}{l}\text { Anticancer, anti-inflammatory, } \\
\text { anti-oxidant, can lower blood } \\
\text { glucose levels, and neuroprotective } \\
\text { effects, treat AD, Improve memory }\end{array}$ & $\begin{array}{l}\text { Li et al., } 2012 \\
\text { Kumar et al., } 2007 \\
\text { Karthick et al., } 2016 \\
\end{array}$ \\
\hline $\begin{array}{l}\text { Toothed firmoss } \\
\text { Huperzia serrate }\end{array}$ & Huperzine $A$ & $\begin{array}{l}\text { improve memory, AChE inhibitor, } \\
\text { treat } A D\end{array}$ & $\begin{array}{l}\frac{\text { Ha et al., } 2011}{\text { Ratia et al., } 2013} \\
\frac{\text { Wang et al., } 2011}{\text { Rafii et al., } 2011}\end{array}$ \\
\hline
\end{tabular}

AD: Alzheimer's disease; PD: Parkinson disease; MAO: monoamine oxidase; ND: Neurodegenerative diseases;

AChE: acetylcholinesterase 
been shown to have potential in mediating neurotrophins. For instance, 3,7-dihydroxy-2,4,6trimethoxy-phenanthrene, diosniposide $B$, lignan derivatives, ginkgolide $B, 4,6$-dimethoxyphenanthrene2,3,7-triol, spicatoside A, ginsenoside Rg3, limonoid derivatives, quercetin, cyanidin-3-O- $\beta$-glucopyranoside, clerodane diterpenoids, apigenin derivatives, and quinic acid derivatives can prevent neurodegeneration by inducing neurotrophic factors and boosting anti-oxidant activity, and inhibit the production of ROS and inflammatory mediators (details of mechanism can be obtained from Venkatesan et al., 2015). Furthermore, neurotrophic factors and the Wnt pathway play a critical role in restoring synaptic loss and behavioural deficits (Eyjolfsdottir et al., 2016).

Phytochemical compounds with anti-oxidant and antiinflammatory activities have the potential to treat ND. Good examples of these are flavonoids which possess high anti-oxidant properties. Flavonoids have low molecular weight, and they belong to polyphenolic antioxidants present in fruits, vegetables, and beverages such as wine and tea (Panche et al., 2016). In addition, these flavonoids can also be found in the roots and leaves of Andrographis paniculate (known as Hempedu bumi in Malay) (Subramaniam et al., 2015). Ficus deltoidei consists of at least 25 different flavonoids with high anti-oxidant properties (Azemin et al., 2014; Hakiman \& Maziah, 2009). Flavonoids and tannins derived from Uncaria gambir demonstrated antioxidant properties that prevent damage caused by free radical-mediated processes (Ningsih et al., 2014).

Anthocyanins have anti-inflammatory activity as they inhibit cyclooxygenase enzymes. These flavonoids inhibit the expression of vascular cell adhesion molecules (VCAM), thus inhibiting the reaction and adhesion of endothelial cells with leucocytes. These compounds are believed to decrease the levels of interferon necrotic factor-gamma, interleukin-2 and inhibition of mast cell degranulation (Joseph \& Jini, 2011; Pataki et al., 2002). Ferulic acid, another phenolic acid, has a broad therapeutic effect against neurodegenerative and inflammatory diseases. It is attributed partly due to the anti-oxidant activity of this phenolic acid. The ferulic acid prevents lipid peroxidation and scavenges superoxide free ion radicals (Joshi et al., 2001). This phenolic acid reduces inflammatory mediators like tumour necrotic factoralpha, prostaglandin E2 (Appendino et al., 2006), protects proteins, DNA and lipids from oxidative stress, thus exerting anticancer properties (Delmas et al., 2006).
Tannins which can be found in Eurycoma longifolia possess antibacterial (Danial et al., 2013), antiinflammatory (Varghese et al., 2013), and anti-oxidant due to their high concentration of superoxide dismutase (Mohd Effendy et al., 2012). Tannins are also present in Piper bettle with anti-oxidant and anti-inflammatory activities (Abrahim et al., 2012; Datta et al., 2011; Sripradha, 2014).

Terpenoids present in most plants like Andrographis paniculate, Panax ginseng, Gynura procumbens, Labisia pumila, Orthosiphon stamineus, Phyllanthus niruri. Terpenoids possess both anti-oxidant and antiinflammatory activities. Ginsenosides (one of the terpenoids) from Panax ginseng has been shown to reduce $A \beta$ levels by promoting $A \beta$ degradation and enhancing neprilysin gene expression, a rate-limiting enzyme in $A \beta$ degradation (Yang et al., 2009). Ginkgolides, a cyclic diterpene isolated from Gingko biloba has been extensively studied for its neuroprotective effects (Shi et al., 2009). Cannabinoids are monoterpene derived from Cannabis sativa, inhibiting $A C h E$-induced $A \beta$ aggregation and reduce $A \beta$ induced toxicity (Eubanks et al., 2006). Oleanolic acid from Aralia cordata rescued neuronal death induced by $A \beta$ in cultured rat cortical neurons and improves $A \beta$ induced memory deficit in mice (Cho et al., 2009). Another triterpene isolated from Polygala tenuifolia known as tenuifolin reduces $A \beta$ secretion by inhibiting $\beta$-secretase, one of the enzymes responsible for cleaving APP to A $\beta$ (Lv et al., 2009). Ursolic acid derived from Origanum majorana exhibits a neuroprotective effect against $A \beta$. Ursolic acid can effectively inhibit AChE activity and $A \beta$ binding to microglia, reducing the production of pro-inflammatory cytokines and neurotoxic reactive oxygen species (Wilkinson et al., 2011). Table 1 summarises the selected potential herbal plants with the phytochemical components that show promise for NDs treatment.

Taken together, herbal medicines containing phytoactive compounds may show a great promise for the future treatment and management of NDs. Therefore, to effectively treat NDs, the natural active compounds need to be evaluated, standardised, explored and learned through pre-clinical research using various ND disease models. On the other hand, synthetic medications can temporarily relieve the symptoms and may not be the permanent solution to cure the NDs completely. Together with the help of clinicians and researchers, natural medicines can be made safer and more effective to treat ND patients. Finally, researchers need to explore biological 
mechanisms involved in NDs and expand the knowledge of natural compounds by conducting the fundamental research critical to combat ageing-related NDs.
Acknowledgements: This work was supported by the Universiti Sains Malaysia RUI (1001/CDADAH/8012302).

Conflicts of Interest: The authors declare no conflict of interest.

\section{References}

Abrahim, N. N., Kanthimathi, M. S., \& Abdul-Aziz, A. (2012). Piper betle shows anti-oxidant activities, inhibits MCF-7 cell proliferation and increases activities of catalase and superoxide dismutase. BMC Complementary and Alternative Medicine, 12, 220. https://doi.org/10.1186/1472-6882-12-220

Aggarwal, B. B., Ichikawa, H., Garodia, P., Weerasinghe, P., Sethi, G., Bhatt, I. D., Pandey, M. K., Shishodia, S., \& Nair, M. G. (2006). From traditional Ayurvedic medicine to modern medicine: identification of therapeutic targets for suppression of inflammation and cancer. Expert Opinion on Therapeutic Targets, 10(1), 87-118. https://doi.org/10.1517/14728222.10.1.87

Ahmad, N., Feyes, D. K., Nieminen, A. L., Agarwal, R., \& Mukhtar, H. (1997). Green tea constituent epigallocatechin-3-gallate and induction of apoptosis and cell cycle arrest in human carcinoma cells. Journal of the National Cancer Institute, 89(24), 1881-1886. https://doi.org/10.1093/jnci/89.24.1881

Ali, B. H., Blunden, G., Tanira, M. O., \& Nemmar, A. (2008). Some phytochemical, pharmacological and toxicological properties of ginger (Zingiber officinale Roscoe): a review of recent research. Food and Chemical Toxicology, 46(2), 409420. https://doi.org/10.1016/i.fct.2007.09.085

Alkam, T., Nitta, A., Mizoguchi, H., Itoh, A., \& Nabeshima, T. (2007). A natural scavenger of peroxynitrites, rosmarinic acid, protects against impairment of memory induced by Abeta(25-35). Behavioural Brain Research, 180(2), $139-145$. https://doi.org/10.1016/j.bbr.2007.03.001

Alzheimer's Association (2021). Mortality and Morbidity. In 2021 Alzheimer's Disease Facts and Figures. Alzheimer's Dement 17(3), 28-34. https://www.alz.org/media/documents/alzheimers-facts-and-figures.pdf

Anand, P., \& Singh, B. (2013). A review on cholinesterase inhibitors for Alzheimer's disease. Archives of Pharmacal Research, 36(4), 375-399. https://doi.org/10.1007/s12272-013-0036-3

Ansari, N., \& Khodagholi, F. (2013). Natural products as promising drug candidates for the treatment of Alzheimer's disease: molecular mechanism aspect. Current Neuropharmacology, 11(4), 414-429.

https://doi.org/10.2174/1570159X11311040005

Appendino, G., Maxia, L., Bascope, M., Houghton, P. J., Sanchez-Duffhues, G., Muñoz, E., \& Sterner, O. (2006). A Meroterpenoid NF-KB Inhibitor and Drimane Sesquiterpenoids from Asafetida. Journal of Natural Products, 69(7), 11011104. https://doi.org/10.1021/NP0600954

Azemin, A., Dharmaraj, S., Hamdan, M. R., Mat, N., Ismail, Z., \& Mohd, K. S. (2014). Discriminating Ficus deltoidea var. bornensis from different localities by HPTLC and FTIR fingerprinting. Journal of Applied Pharmaceutical Science, 4(11), 6975. https://doi.org/10.7324/JAPS.2014.41112

Baazaoui, N., \& Iqbal, K. (2018). A Novel Therapeutic Approach to Treat Alzheimer's Disease by Neurotrophic Support During the Period of Synaptic Compensation. Journal of Alzheimer's Disease, 62(3), 1211-1218. https://doi.org/10.3233/JAD170839

Bédard, P., Gauvin, S., Ferland, K., Caneparo, C., Pellerin, È., Chabaud, S., \& Bolduc, S. (2020). Innovative Human ThreeDimensional Tissue-Engineered Models as an Alternative to Animal Testing. Bioengineering (Basel, Switzerland), 7(3), 115. https://doi.org/10.3390/bioengineering7030115

Bereczki, E., Branca, R. M., Francis, P. T., Pereira, J. B., Baek, J. H., Hortobágyi, T., Winblad, B., Ballard, C., Lehtiö, J., \& Aarsland, D. (2018). Synaptic markers of cognitive decline in neurodegenerative diseases: a proteomic approach. Brain, 141(2), 582-595. https://doi.org/10.1093/brain/awx352

Biasibetti, R., Tramontina, A. C., Costa, A. P., Dutra, M. F., Quincozes-Santos, A., Nardin, P., Bernardi, C. L., Wartchow, K. M., Lunardi, P. S., \& Gonçalves, C. A. (2013). Green tea (-)epigallocatechin-3-gallate reverses oxidative stress and reduces acetylcholinesterase activity in a streptozotocin-induced model of dementia. Behavioural Brain Research, 236(1), 186193. https://doi.org/10.1016/j.bbr.2012.08.039

Bischoff, S. C. (2008). Quercetin: potentials in the prevention and therapy of disease. Current Opinion in Clinical Nutrition and Metabolic Care, 11(6), 733-740. https://doi.org/10.1097/MCO.0b013e32831394b8

Borek, C. (2006). Garlic reduces dementia and heart-disease risk. The Journal of Nutrition, 136(3 Suppl), 810S-812S. https://doi.org/10.1093/in/136.3.810S

Chen, C. L., Tsai, W. H., Chen, C. J., \& Pan, T. M. (2015). Centella asiatica extract protects against amyloid $\beta 1-40$-induced neurotoxicity in neuronal cells by activating the antioxidative defence system. Journal of Traditional and Complementary Medicine, 6(4), 362-369. https://doi.org/10.1016/i.jtcme.2015.07.002

Cho, I. H. (2012). Effects of Panax ginseng in Neurodegenerative Diseases. Journal of Ginseng Research, 36(4), 342-353. https://doi.org/10.5142/igr.2012.36.4.342 
Cho, S. O., Ban, J. Y., Kim, J. Y., Jeong, H. Y., Lee, I. S., Song, K. S., Bae, K., \& Seong, Y. H. (2009). Aralia cordata protects against amyloid beta protein (25-35)-induced neurotoxicity in cultured neurons and has antidementia activities in mice. Journal of Pharmacological Sciences, 111, 22-32. https://doi.org/10.1254/iphs.08271FP

Chow, T. W., Pollock, B. G., \& Milgram, N. W. (2007). Potential cognitive enhancing and disease modification effects of SSRIs for Alzheimer's disease. Neuropsychiatric Disease and Treatment, 3(5), 627-636.

Coovert, D. D., Le, T. T., McAndrew, P. E., Strasswimmer, J., Crawford, T. O., Mendell, J. R., Coulson, S. E., Androphy, E. J., Prior, T. W., \& Burghes, A. H. (1997). The survival motor neuron protein in spinal muscular atrophy. Human Molecular Genetics, 6(8), 1205-1214. https://doi.org/10.1093/hmg/6.8.1205

Danial, M., Saghal, G., Mubbarakh, S. A., Sundarasekar, J., \& Subramaniam, S. (2013). Antibacterial studies on in vivo plant parts of medicinally important Eurycoma longifolia (Tongkat Ali). Pakistan Journal of Botany, 45(5), 1693-1700.

Datta, A., Ghoshdastidar, S., \& Singh, M. (2011). Antimicrobial property of Piper betel leaf against clinical isolates of bacteria. International Journal of Pharmaceutical Sciences and Research, 2, 104-109.

Dauer, W., \& Przedborski, S. (2003). Parkinson's disease: mechanisms and models. Neuron, 39(6), 889-909. https://doi.org/10.1016/s0896-6273(03)00568-3

Defeudis, F. V. (2002). Bilobalide and neuroprotection. Pharmacological Research, 46(6), 565-568. https://doi.org/10.1016/s1043-6618(02)00233-5

Delmas, D., Lançon, A., Colin, D., Jannin, B., \& Latruffe, N. (2006). Resveratrol as a chemopreventive agent: a promising molecule for fighting cancer. Current Drug Targets, 7, 423-442.

Dhanasekaran, M., Holcomb, L. A., Hitt, A. R., Tharakan, B., Porter, J. W., Young, K. A., \& Manyam, B. V. (2009). Centella asiatica extract selectively decreases amyloid beta levels in hippocampus of Alzheimer's disease animal model. Phytotherapy Research, 23(1), 14-19. https://doi.org/10.1002/ptr.2405

Dugger, B. N., \& Dickson, D. W. (2017). Pathology of Neurodegenerative Diseases. Cold Spring Harbor Perspectives in Biology, 9(7), a028035. https://doi.org/10.1101/cshperspect.a028035

Durairajan, S. S., Liu, L. F., Lu, J. H., Chen, L. L., Yuan, Q., Chung, S. K., Huang, L., Li, X. S., Huang, J. D., \& Li, M. (2012). Berberine ameliorates $\beta$-amyloid pathology, gliosis, and cognitive impairment in an Alzheimer's disease transgenic mouse model. Neurobiology of Aging, 33(12), 2903-2919. https://doi.org/10.1016/i.neurobiolaging.2012.02.016

Essa, M. M., Vijayan, R. K., Castellano-Gonzalez, G., Memon, M. A., Braidy, N., \& Guillemin, G. J. (2012). Neuroprotective effect of natural products against Alzheimer's disease. Neurochemical Research, 37(9), 1829-1842. https://doi.org/10.1007/s11064-012-0799-9

Eubanks, L. M., Rogers, C. J., Beuscher, A. E., IV, Koob, G. F., Olson, A. J., Dickerson, T. J., \& Janda, K.D. (2006). A molecular link between the active component of marijuana and Alzheimer's disease pathology. Molecular Pharmaceutics, 3(6), 773777. https://doi.org/10.1021/mp060066m

Eyjolfsdottir, H., Eriksdotter, M., Linderoth, B., Lind, G., Juliusson, B., Kusk, P., Almkvist, O., Andreasen, N., Blennow, K., Ferreira, D., Westman, E., Nennesmo, I., Karami, A., Darreh-Shori, T., Kadir, A., Nordberg, A., Sundström, E., Wahlund, L. O., Wall, A., Wiberg, M., ... Almqvist, P. (2016). Targeted delivery of nerve growth factor to the cholinergic basal forebrain of Alzheimer's disease patients: application of a second-generation encapsulated cell biodelivery device. Alzheimer's Research \& Therapy, 8(1), 30. https://doi.org/10.1186/s13195-016-0195-9

Funk, J. L., Frye, J. B., Oyarzo, J. N., Kuscuoglu, N., Wilson, J., McCaffrey, G., Stafford, G., Chen, G., Lantz, R. C., Jolad, S. D., Sólyom, A. M., Kiela, P. R., \& Timmermann, B. N. (2006). Efficacy and mechanism of action of turmeric supplements in the treatment of experimental arthritis. Arthritis and Rheumatism, 54(11), 3452-3464. https://doi.org/10.1002/art.22180

Gan, L., Cookson, M. R., Petrucelli, L., \& La Spada A.R. (2018). Converging pathways in neurodegeneration, from genetics to mechanisms. Nature Neuroscience, 21, 1300-1309. https://doi.org/10.1038/s41593-018-0237-7

Gohil, K., \& Patel, J. (2010). A review on Bacopa monniera: Current research and future prospects. International Journal of Green Pharmacy, 4(1). 1-9. https://doi.org/10.4103/0973-8258.62156

Ha, G. T., Wong, R. K., \& Zhang, Y. (2011). Huperzine a as potential treatment of Alzheimer's disease: an assessment on chemistry, pharmacology, and clinical studies. Chemistry \& Biodiversity, 8(7), 1189-1204. https://doi.org/10.1002/cbdv.201000269

Hakiman, M., \& Maziah, M. (2009). Non enzymatic and enzymatic anti-oxidant activities in aqueous extract of different Ficus deltoidea accessions. Journal of Medicinal Plants Research, 3(3), 120-131.

Hamaguchi, T., Ono, K., \& Yamada, M. (2010). REVIEW: Curcumin and Alzheimer's disease. CNS Neuroscience \& Therapeutics, 16(5), 285-297. https://doi.org/10.1111/j.1755-5949.2010.00147.x

Harvard NeuroDiscovery Center (2021). The Challenge of Neurodegenerative Diseases. Retrieved June 15, $2021 \mathrm{from}$ https://neurodiscovery.harvard.edu/challenge

Hong, S., Beja-Glasser, V. F., Nfonoyim, B. M., Frouin, A., Li, S., Ramakrishnan, S., Merry, K. M., Shi, Q., Rosenthal, A., Barres, B. A., Lemere, C. A., Selkoe, D. J., \& Stevens, B. (2016). Complement and microglia mediate early synapse loss in Alzheimer mouse models. Science, 352(6286), 712-716. https://doi.org/10.1126/science.aad8373 
Howes, M. J., Perry, N. S., \& Houghton, P. J. (2003). Plants with traditional uses and activities, relevant to the management of Alzheimer's disease and other cognitive disorders. Phytotherapy Research, 17(1), 1-18. https://doi.org/10.1002/ptr.1280

Huang, M., Jiang, X., Liang, Y., Liu, Q., Chen, S., \& Guo, Y. (2017). Berberine improves cognitive impairment by promoting autophagic clearance and inhibiting production of $\beta$-amyloid in APP/tau/PS1 mouse model of Alzheimer's disease. Experimental Gerontology, 91, 25-33. https://doi.org/10.1016/i.exger.2017.02.004

Jiménez-Aliaga, K., Bermejo-Bescós, P., Benedí, J., \& Martín-Aragón, S. (2011). Quercetin and rutin exhibit antiamyloidogenic and fibril-disaggregating effects in vitro and potent antioxidant activity in APPswe cells. Life Sciences, 89(25-26), 939945. https://doi.org/10.1016/j.Ifs.2011.09.023

Joseph, B., \& Jini, D. (2011). Insight into the hypoglycaemic effect of traditional Indian herbs used in the treatment of diabetes. Research Journal of Medicinal Plant, 5, 352-376.

Joshi, S. S., Kuszynski, C. A., \& Bagchi, D. (2001). The cellular and molecular basis of health benefits of grape seed proanthocyanidin extract. Current Pharmaceutical Biotechnology, 2, 187-200.

Kantar Gok, D., Ozturk, N., Er, H., Aslan, M., Demir, N., Derin, N., Agar, A., \& Yargicoglu, P. (2015). Effects of rosmarinic acid on cognitive and biochemical alterations in ovariectomised rats treated with D-galactose. Folia Histochemica et Cytobiologica, 53(4), 283-293. https://doi.org/10.5603/fhc.a2015.0034

Karthick, C., Periyasamy, S., Jayachandran, K. S., \& Anusuyadevi, M. (2016). Intrahippocampal Administration of Ibotenic Acid Induced Cholinergic Dysfunction via NR2A/NR2B Expression: Implications of Resveratrol against Alzheimer Disease Pathophysiology. Frontiers in Molecular Neuroscience, 9, 28. https://doi.org/10.3389/fnmol.2016.00028

Kashyap, G., Bapat, D., Das, D., Gowaikar, R., Amritkar, R. E., Rangarajan, G., Ravindranath, V., \& Ambika, G. (2019). Synapse loss and progress of Alzheimer's disease -A network model. Scientific Reports, 9(1), 1-9. https://doi.org/10.1038/s41598019-43076-y

Kim, J., Lee, H. J., \& Lee, K. W. (2010). Naturally occurring phytochemicals for the prevention of Alzheimer's disease. Journal of Neurochemistry, 112(6), 1415-1430. https://doi.org/10.1111/i.1471-4159.2009.06562.x

Kovacs, G. G. (2016). Molecular Pathological Classification of Neurodegenerative Diseases: Turning towards Precision Medicine. International Journal of Molecular Sciences, 17(2), 189. https://doi.org/10.3390/ijms17020189

Kulkarni, S. K., \& Dhir, A. (2010). Berberine: a plant alkaloid with therapeutic potential for central nervous system disorders. Phytotherapy Research, 24(3), 317-324. https://doi.org/10.1002/ptr.2968

Kumar, A., Naidu, P. S., Seghal, N., \& Padi, S. S. (2007). Neuroprotective effects of resveratrol against intracerebroventricular colchicine-induced cognitive impairment and oxidative stress in rats. Pharmacology, 79(1), 17-26. https://doi.org/10.1159/000097511

Lee, J. W., Lee, Y. K., Ban, J. O., Ha, T. Y., Yun, Y. P., Han, S. B., Oh, K. W., \& Hong, J. T. (2009). Green tea (-)-epigallocatechin-3gallate inhibits beta-amyloid-induced cognitive dysfunction through modification of secretase activity via inhibition of ERK and NF-kappaB pathways in mice. The Journal of nutrition, 139(10), 1987-1993. https://doi.org/10.3945/jn.109.109785

Li, F., Gong, Q., Dong, H., \& Shi, J. (2012). Resveratrol, a neuroprotective supplement for Alzheimer's disease. Current Pharmaceutical Design, 18(1), 27-33. https://doi.org/10.2174/138161212798919075

Licker, V., Kövari, E., Hochstrasser, D. F., \& Burkhard, P. R. (2009). Proteomics in human Parkinson's disease research. Journal of Proteomics, 73(1), 10-29. https://doi.org/10.1016/i.jprot.2009.07.007

Lv, J., Jia, H., Jiang, Y., Ruan, Y., Liu, Z., Yue, W., Beyreuther, K., Tu, P., \& Zhang, D. (2009). Tenuifolin, an extract derived from tenuigenin, inhibits amyloid-beta secretion in vitro. Acta Physiologica, 196(4), 419-425. https://doi.org/10.1111/j.17481716.2009.01961.x

Malik, J., Karan, M., \& Vasisht, K. (2011). Nootropic, anxiolytic and CNS-depressant studies on different plant sources of shankhpushpi. Pharmaceutical Biology, 49(12), 1234-1242. https://doi.org/10.3109/13880209.2011.584539

Marks, S. M., Lockhart, S. N., Baker, S. L., \& Jagust, W. J. (2017). Tau and $\beta$-amyloid are associated with medial temporal lobe structure, function, and memory encoding in normal aging. Journal of Neuroscience, 37(12), 3192-3201. https://doi.org/10.1523/JNEUROSCI.3769-16.2017

Medzhitov, R. (2008). Origin and physiological roles of inflammation. Nature, 454(7203), 428-435. https://doi.org/10.1038/nature07201

Mehrpour, M., \& Codogno, P. (2010). Prion protein: From physiology to cancer biology. Cancer Letters, 290(1), 1-23. https://doi.org/10.1016/j.canlet.2009.07.009

Mishra, S., \& Palanivelu, K. (2008). The effect of curcumin (turmeric) on Alzheimer's disease: An overview. Annals of Indian Academy of Neurology, 11(1), 13-19. https://doi.org/10.4103/0972-2327.40220

Mohd Effendy, N., Mohamed, N., Muhammad, N., Naina Mohamad, I., \& Shuid, A. N. (2012). Eurycoma longifolia: Medicinal plant in the prevention and treatment of male osteoporosis due to androgen deficiency. Evidence-based Complementary and Alternative Medicine, 2012, 125761. https://doi.org/10.1155/2012/125761

Moss, M., Cook, J., Wesnes, K., \& Duckett, P. (2003). Aromas of rosemary and lavender essential oils differentially affect cognition and mood in healthy adults. International Journal of Neuroscience, 113(1), 15-38.

https://doi.org/10.1080/00207450390161903 
Nillert, N., Pannangrong, W., Welbat, J. U., Chaijaroonkhanarak, W., Sripanidkulchai, K., \& Sripanidkulchai, B. (2017). Neuroprotective effects of aged garlic extract on cognitive dysfunction and neuroinflammation induced by $\beta$-amyloid in rats. Nutrients, 9(1), 24. https://doi.org/10.3390/nu9010024

Ningsih, S., Fachrudin, F., Rismana, E., Purwaningsih, E. H., Sumaryono, W., \&. Jusman, S. W. A. (2014). Evaluation Of antilipid peroxidation activity of gambir extract on liver homogenat in vitro. International Journal of PharmTech Research, 6, 982989.

Oboh, G., Ademiluyi, A. O., \& Akinyemi, A. J. (2012). Inhibition of acetylcholinesterase activities and some pro-oxidant induced lipid peroxidation in rat brain by two varieties of ginger (Zingiber officinale). Experimental and Toxicologic Pathology, 64(4), 315-319. https://doi.org/10.1016/i.etp.2010.09.004

Ossola, B., Kääriäinen, T. M., \& Männistö, P. T. (2009). The multiple faces of quercetin in neuroprotection. Expert Opinion on Drug Safety, 8(4), 397-409. https://doi.org/10.1517/14740330903026944

Panche, A. N., Diwan, A. D., \& Chandra, S. R. (2016). Flavonoids: an overview. Journal of nutritional science, 5, e47. https://doi.org/10.1017/jns.2016.41

Pataki, T., Bak, I., Kovacs, P., Bagchi, D., Das, D. K., \& Tosaki, A. (2002). Grape seed proanthocyanidins improved cardiac recovery during reperfusion after ischemia in isolated rat hearts. The American Journal of Clinical Nutrition, 75(5), 894899. https://doi.org/10.1093/AJCN/75.5.894

Petersen, M., \& Simmonds, M. S. (2003). Rosmarinic acid. Phytochemistry, 62(2), 121-125. https://doi.org/10.1016/s00319422(02)00513-7

Pilotto, F., \& Saxena , S. (2018). Epidemiology of inherited cerebellar ataxias and challenges in clinical research. Clinical \& Translational Neuroscience, 2(2), 1-12. https://doi.org/10.1177/2514183X18785258

Prentice, H., Modi, J. P., \& Wu, J. Y. (2015). mechanisms of neuronal protection against excitotoxicity, endoplasmic reticulum stress, and mitochondrial dysfunction in stroke and neurodegenerative diseases. Oxidative Medicine and Cellular Longevity, 2015, 964518. https://doi.org/10.1155/2015/964518

Rafii, M. S., Walsh, S., Little, J. T., Behan, K., Reynolds, B., Ward, C., Jin, S., Thomas, R., Aisen, P. S., \& Alzheimer's Disease Cooperative Study. (2011). A phase II trial of huperzine A in mild to moderate Alzheimer disease. Neurology, 76(16), 1389-1394. https://doi.org/10.1212/WNL.0b013e318216eb7b

Ramaswamy, S., McBride, J. L., \& Kordower, J. H. (2007). Animal Models of Huntington's Disease. ILAR Journal, 48(4), 356373. https://doi.org/10.1093/ilar.48.4.356

Ratia, M., Giménez-Llort, L., Camps, P., Muñoz-Torrero, D., Pérez, B., Clos, M. V., \& Badia, A. (2013). Huprine X and huperzine A improve cognition and regulate some neurochemical processes related with Alzheimer's disease in triple transgenic mice (3xTg-AD). Neuro-degenerative Diseases, 11(3), 129-140. https://doi.org/10.1159/000336427

Relja, M. (2004). Pathophysiology and classification of neurodegenerative diseases. EJIFCC, 15(3), 97-99.

Roos, R. A. (2010). Huntington's disease: a clinical review. Orphanet Journal of Rare Diseases, 5, 40. https://doi.org/10.1186/1750-1172-5-40

Russo, M., Spagnuolo, C., Tedesco, I., Bilotto, S., \& Russo, G. L. (2012). The flavonoid quercetin in disease prevention and therapy: facts and fancies. Biochemical Pharmacology, 83(1), 6-15. https://doi.org/10.1016/i.bcp.2011.08.010

Salter, M. W., \& Stevens, B. (2017). Microglia emerge as central players in brain disease. Nature Medicine, 23(9), $1018-1027$. https://doi.org/10.1038/NM.4397

Sethiya, N. K., Nahata, A., Mishra, S. H., \& Dixit, V. K. (2009). An update on Shankhpushpi, a cognition-boosting Ayurvedic medicine. Journal of Chinese Integrative Medicine, 7(11), 1001-1022. https://doi.org/10.3736/jcim20091101

Sharifi-Rad, J., Melgar-Lalanne, G., Hernández-Álvarez, Javier, A., Taheri, Y., Shaheen, S., Kregiel, D., Antolak, H., Pawlikowska, E., Brdar-Jokanović, M., Rajkovic, J., Hosseinabadi, T., Ljevnaić-Mašić, B., Baghalpour, N., Mohajeri, M., Fokou, P. V. T., \& Martins, N. (2020a). Malva species: Insights on its chemical composition towards pharmacological applications. Phytotherapy Research, 34(3), 546-567. https://doi.org/10.1002/PTR.6550

Sharifi-Rad, M., Lankatillake, C., Dias, D. A., Docea, A. O., Mahomoodally, M. F., Lobine, D., Chazot, P. L., Kurt, B., Tumer, T. B., Moreira, A. C., Sharopov, F., Martorell, M., Martins, N., Cho, W. C., Calina, D., \& Sharifi-Rad, J. (2020b). Impact of natural compounds on neurodegenerative disorders: from preclinical to pharmacotherapeutics. Journal of Clinical Medicine, 9(4), 1061. https://doi.org/10.3390/jcm9041061

Sheng, M., Sabatini, B. L., \& Südhof, T. C. (2012). Synapses and Alzheimer's disease. Cold Spring Harbor Perspectives in Biology, 4(5), a005777. https://doi.org/10.1101/cshperspect.a005777

Shi, C., Zhao, L., Zhu, B., Li, Q., Yew, D. T., Yao, Z., \& Xu, J. (2009). Protective effects of Ginkgo biloba extract (EGb761) and its constituents quercetin and ginkgolide B against beta-amyloid peptide-induced toxicity in SH-SY5Y cells. ChemicoBiological Interactions, 181(1), 115-123. https://doi.org/10.1016/i.cbi.2009.05.010

Slanzi, A., Iannoto, G., Rossi, B., Zenaro, E., \& Constantin, G. (2020). In vitro models of neurodegenerative diseases. Frontiers in Cell and Developmental Biology, 8, 328. https://doi.org/10.3389/fcell.2020.00328

Sripradha, S., (2014). Betel leaf-the green gold. Journal of Phamaceutical Sciences and Research, 6(1), 36-37. 
Subramaniam, S., Hedayathullah Khan, H. B., Elumalai, N., \& Sudha Lakshmi, S. Y. (2015). Hepatoprotective effect of ethanolic extract of whole plant of Andrographis paniculata against CCl4-induced hepatotoxicity in rats. Comparative Clinical Pathology 2015 24:5, 24(5), 1245-1251. https://doi.org/10.1007/S00580-015-2067-2

Tawab, M. A., Bahr, U., Karas, M., Wurglics, M., \& Schubert-Zsilavecz, M. (2003). Degradation of ginsenosides in humans after oral administration. Drug Metabolism and Disposition, 31(8), 1065-1071. https://doi.org/10.1124/dmd.31.8.1065

Tchantchou, F., Lacor, P. N., Cao, Z., Lao, L., Hou, Y., Cui, C., Klein, W. L., \& Luo, Y. (2009). Stimulation of neurogenesis and synaptogenesis by bilobalide and quercetin via common final pathway in hippocampal neurons. Journal of Alzheimer's disease, 18(4), 787-798. https://doi.org/10.3233/JAD-2009-1189

Trancikova, A., Ramonet, D., \& Moore, D. J. (2011). Genetic mouse models of neurodegenerative diseases. Progress in Molecular Biology and Translational Science, 100, 419-482. https://doi.org/10.1016/B978-0-12-384878-9.00012-1

van Beek, T. A. (2002). Chemical analysis of Ginkgo biloba leaves and extracts. Journal of chromatography A, 967(1), 21-55. https://doi.org/10.1016/s0021-9673(02)00172-3

Varghese, C. P., Ambrose, C., Jin, S. C., Lim, Y. J., \& Keisaban, T. (2013). Anti-oxidant and anti-inflammatory activity of Eurycoma longifolia Jack, a traditional medicinal plant in Malaysia. International Journal of Pharmaceutical Sciences and Nanotechnology, 5, 1875-1878. https://doi.org/10.37285/ijpsn.2012.5.4.7

Venkatesan, R., Ji, E., \& Kim, S. Y. (2015). Phytochemicals that regulate neurodegenerative disease by targeting neurotrophins: a comprehensive review. BioMed Research International, 2015, 814068. https://doi.org/10.1155/2015/814068

Wang, C. Y., Zheng, W., Wang, T., Xie, J. W., Wang, S. L., Zhao, B. L., Teng, W. P., \& Wang, Z. Y. (2011). Huperzine A activates Wnt/ $\beta$-catenin signaling and enhances the nonamyloidogenic pathway in an Alzheimer transgenic mouse model. Neuropsychopharmacology, 36(5), 1073-1089. https://doi.org/10.1038/npp.2010.245

Wang, W. Y., Tan, M. S., Yu, J. T., \& Tan, L. (2015). Role of pro-inflammatory cytokines released from microglia in Alzheimer's disease. Annals of Translational Medicine, 3(10), 136. https://doi.org/10.3978/i.issn.2305-5839.2015.03.49

Wilkinson, K., Boyd, J. D., Glicksman, M., Moore, K. J., \& El Khoury, J. (2011). A high content drug screen identifies ursolic acid as an inhibitor of amyloid beta protein interactions with its receptor CD36. Journal of Biological Chemistry, 286, 3491434922. https://doi.org/10.1074/jbc.m111.232116

Wolozin, B., \& Behl, C. (2000). Mechanisms of neurodegenerative disorders: Part 1: Protein aggregates. Archives of Neurology, 57(6),793-796. https://doi.org/10.1001/archneur.57.6.793

Yakoot, M., Salem, A., \& Helmy, S. (2013). Effect of Memo ${ }^{\circledR}$, a natural formula combination, on Mini-Mental State Examination scores in patients with mild cognitive impairment. Clinical Interventions in Aging, 8, 975-981. https://doi.org/10.2147/CIA.S44777

Yalcin, G., \& Yalcin, A. (2018). Metabolic syndrome and neurodegenerative diseases. Journal of Geriatric Medicine and Gerontology, 4, 042. https://doi.org/10.23937/2469-5858/1510042

Yang, L., Hao, J., Zhang, J., Xia, W., Dong, X., Hu, X., Kong, F., \& Cui, X. (2009). Ginsenoside Rg3 promotes beta-amyloid peptide degradation by enhancing gene expression of neprilysin. The Journal of Pharmacy and Pharmacology, 61(3), 375-380. https://doi.org/10.1211/JPP/61.03.0013

Zhu, F., \& Qian, C. (2006). Berberine chloride can ameliorate the spatial memory impairment and increase the expression of interleukin-1beta and inducible nitric oxide synthase in the rat model of Alzheimer's disease. BMC Neuroscience, 7, 78. https://doi.org/10.1186/1471-2202-7-78 